\title{
필리핀 미곡 종합처리장(RPC) 건립사업 \\ 사후평가 보고서
}

\section{I. 배경 및 필요성}

\section{1. 필리핀 농업 현황}

필리핀은 높은 성장과 개발 잠재력을 보유하고 있으나, 저성장과 누적된 외채 등으로 인하여 여전 히 빈곤국가에 속해 있는 상황이다. 2003년 기준, 필리핀의 산업구조에서 GDP의 약 $20 \%$ 가 농업 부분과 직접 관련이 있으며, 이중 약 $30 \%$ 는 농업관련 산업 및 서비스와 간접연관이 있을 정도로 농 업이 차지하는 비중이 크다. 농업부문 종사자는 인구 대비로는 총고용의 약 $39 \%$ 를 차지하며, 31 백 만명으로 추산되는 필리핀 빈민 중 $69 \%$ 인 21 백만명이 농업부문에 의존하고 있는 실정이다.

그러나 필리핀 농업부문의 국제경쟁력은 매우 낮은데, 이는 (1) 비료 등 생산 투입요소의 고비용, (2) 과다한 수확량 손실, (3) 토지상속권 이전(토지개혁 미실현)에 따른 생산의 연속성 단절 등이 그 요인이다. 이 중 두 번째 문제점인 '과다한 수확량 손실'과 관련하여, 벼 수확 후 건조 및 도정과정 에서 총생산의 약 $20 \%$ 가량이 손실되고 쌀 품질이 떨어지는 등의 문제점이 지적되었으며 이에 따른 해결 방안으로 현대적인 미곡 종합처리장 $(\mathrm{RPC})$ 의 도입이 적극 요청될 것으로 판단되었다. 특히 빈 곤층의 60 70\%가 농업에 의존하고 있는 상황에서 동부분에 대한 지원은 필리핀의 빈곤감소에 기 여하는 의미가 크다고 하겠다.

\section{2. 본 사업의 필요성}

필리핀 국가개발 및 수원총괄기관인 경제개발청 $(\mathrm{NEDA})$ 은 정부의 농업부분 생산성 향상이 국가개 발계획의 우선순위상 시급한 과제임을 확인하며 본 사업의 중요성을 강조하였다. 필리핀의 중기경 제개발계획(Medium-Term Philippine Plan/, '04 '10)에서는 농업의 국제경쟁력 취약원인의 하 나로서 수확 후 관리 인프라의 부재를 들고 있으며, 이를 보완하기위해 현대식 미곡종합처리장(이 하 RPC :Rice Processing and Milling Complex) 건설의 추진이 시급함을 인식하였다. 
필리핀의 수확 후 관리기계 보유현황을 살펴보면, 총 벼 생산량 13.6 백만톤에 대해서 탈곡기는 과 잉 공급된 상황이고, 건조는 $95 \%$ 가 콘크리트 바닥에서 태양건조로 이뤄지고 있었으며, 저장고의 용량은 생산량의 $10 \%$ 에도 미치지 못하는 실정이었다. 정미기는 과잉공급된 것으로 보이나 고품질 도정을 위한 멀티패스(Multi-pass) 정미기의 이용률은 전체 생산량의 $7 \%$ 수준임을 고려할 때 필 리핀 농업의 현 상황에서 현대식 $\mathrm{RPC}$ 기술공급은 매우 절실하다고 판단되었다.

\section{II. 사업개요}

\section{1. 사업대상 지역현황 및 배경}

필리핀 수도 마닐라의 동북쪽에 위치한 오로라주는 태평양에 접해 있어 연중 고른 강우량을 기록하 며, 인구의 약 $3 / 4$ 이 농촌에 거주한다. 농업이 이 지역의 주산업임에도 지역 내에 현대적인 RPC 시 설이 부재한 상황이었다. 기후적으로도 매년 수차례 태풍 등의 재해를 당하는 등의 어려움을 겪어 왔다. 또한 지역 내에 현대적인 $\mathrm{RPC}$ 시설이 부재함에 따라, 수확된 벼가 인근 주로 수출된 후, 도 정된 쌀이 다시 반입되는 과정에서 농민과 소비자가 모두 불이익을 받고 있었다.

이러한 상황을 종합해 볼 때, 오로라주 RPC 건립사업은 농업생산성 향상은 물론 현지 주민들의 복 지 향상을 도모할 수 있는 시범적 사업으로 판단되어 본 사업을 추진하게 되었다.

\section{2. 사업의 목적}

본 사업의 목적은 현대화된 미곡 생산기술 및 설비를 갖춘 $\mathrm{RPC}$ 설립을 통해 미곡생산에서 판매에 이르기까지 효율적 생산관리시스템 및 영농기계화를 구축하고, 이에 따른 농민의 소득증진을 도모 하는데 있다.

\section{3. 추진 경과 및 사업개요}

본 사업은 2005년 예비조사로부터 2006년 시설 건립 완료까지 2년이 소요되었으며, 2007년부터 시험 가동을 시작하였다. 본 사업의 개요는〈표 1〉과 같다. 
〈표 1〉사업 개요

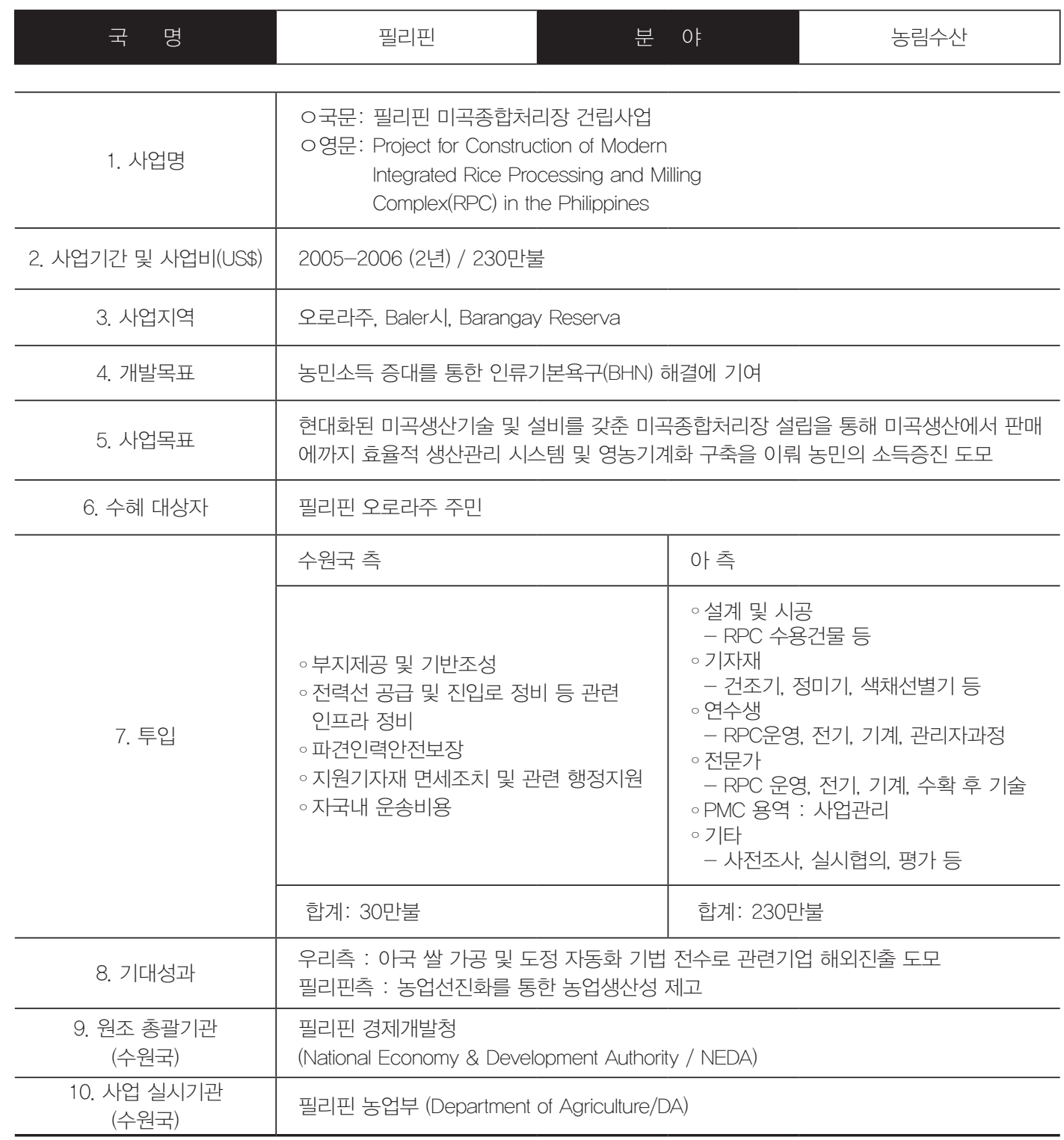

\section{4. 본 사업을 통해 예상되는 효과}

본 사업을 통해 예상된 이득은 경제적, 기술적, 사회 및 환경적 측면에서 고려해 볼 수 있는데, 우 선 경제적 이득은 다음과 같다. 첫째, 벼수확 후 손실감소 및 부가가치 증대에 따른 생산효율성 및 경쟁력 향상, 둘째, Aurora州 식량자급자족 달성과 쌀 수입억제 및 쌀 수출로의 전향 셋째, 쌀 생 산 및 품질향상, 넷째, 민간융자 감소 등으로 인한 농민수익 배가 효과 창출 등이다. 
기술적 측면에서는, $\mathrm{RPC}$ 운용의 자동제어시스템 등 최신 현대기술의 도입, 벼 품종 구매로부터 판 매까지 종합관리시스템 구축, 쌀 생산향상을 위한 품질관리시스템 구축 등을 들 수 있다.

사회 · 환경적 측면에서는 첫째, 농민생활의 질 향상을 위한 원스톱 미곡처리 서비스 실현, 둘째, 본 $\mathrm{RPC}$ 의 사회 · 문화적 센터 역할 수행, 셋째, 쌀겨를 활용한 무기질 비료를 통한 환경적 토양부식 방지 등의 효과를 예상할 수 있다.

\section{5. 평가방법}

본 사업의 평가를 위해 우선적으로는 본 사업과 관련된 사전조사 결과보고서, 종료 평가 결과보고 서, 성과평가 보고서 등을 통한 문헌 검토를 실시하였다. 두 번째로는 설문지 조사를 통하여 $\mathrm{RPC}$ 사업장의 현황을 조사하였으며, 직원들에 대한 설문도 실시하였다. 세 번째로는 현지 관련 공무원 (5명) 및 농민대표(5명), RPC직원(10명) 면담을 통한 평가를 실시하였다.

사후 평가는 2008년 10월 12 일부터 10월 18일까지 총 7일의 일정으로 실시되었으며, 평가는 본 사업과 관련된 필리핀 경제개발청 사업평가실(NEDA Project Monitoring Staff), 농업부(DA) 및 $\mathrm{BPRE}$ 와 사업성과 등의 협의, 오로라주지사 예방, 타 지역에 위치한 $\mathrm{RPC}$ 견학, $\mathrm{RPC}$ 운영과 관련 된 직원, 관련 공무원 및 농민과의 면담 조사 등의 순서로 이루어졌다.

\section{III. 평가 결과}

\section{1. 적절성 (Relevancy)}

적절성 평가는 사업 수원국의 수요 및 정책과의 연관성, 사업계획 수립의 적절성, 사업 추진방식의 적절성, 이해 관계자 분석 여부 등을 평가하는 것에 초점을 두고 이루어진다.

\section{가. 수원국의 수요 및 정책과의 연관성}

필리핀 전체 국토의 약 $40.9 \%$ 가 농경지에 해당하며, 농업분야는 필리핀 전체 GDP의 총 $14 \%$ 를 차지한다. 전체 인구의 약 $38.0 \%$ 가 농촌에 거주하고, 취업자중 농업부분 취업자 비율이 $37.4 \%$ 에 달하는 농업 기반의 국가이다. 쌀은 필리핀의 주곡이며 높은 생산 잠재력을 지녔음에도 자급하 지 못하고 있는 실정이다. 수치상 전체 경지 면적의 약 $33 \%$ 정도에서 쌀을 경작하고 있지만 연평 
균 $2.3 \%$ 의 높은 인구 증가율 및 쌀 수입 정책의 도입으로 인해 필리핀의 쌀 자급률은 2007 년 현재 89.8\%에 머물고 있는 상황이다.

특히 필리핀의 경우, 전체 생산량의 약 $14.8 \%$ 정도가 수확 후 손실로 없어지는 것으로 나타나고 있 기 때문에, 수확 후 손실 방지는 필리핀 쌀 자급자족에 매우 중요한 요소라고 할 수 있다. 수확 후 손실의 $30 \%$ 는 건조 과정에서, $21 \%$ 는 도정 과정, $18 \%$ 는 저장 과정, $15 \%$ 는 탈곡 과정에서, $12 \%$ 정도는 수확 과정에서 그리고 $4 \%$ 정도는 야적 과정에서 없어지는 것으로 분석된다. 따라서 수확 후 손실되는 양을 약 $15 \%$ 에서 $8 \%$ 로, 약 $7 \%$ 정도를 감소시킬 경우 그 양은 필리핀의 쌀 수입물량의 $1 / 3$ 에 달할 정도로 효과가 크다.

이러한 효과를 고려할 때, 현재 필리핀 전체적으로 수확 후 손실을 방지하는데 필요한 건조 및 저장 시설의 용량이 매우 부족한 실정이므로, 수확 후 손실 방지를 위한 미곡종합처리장 건립사업은 필 리핀의 쌀 자급자족 달성을 위해 매우 중요한 의의를 가진다고 평가할 수 있다.

\section{나. 사업 계획 수립의 적절성}

본 사업은 2005년 5월 사전 조사 실시, 2005년 9월 실시협의를 거쳐 사업계획이 마련되었다. $\mathrm{KOICA}$ 에서는 「RPC 설계-시공-가동」의 일괄수주(Turn-key base) 용역과 「관리-자문」의 $\mathrm{PMC}$ 용역으로 구분한 사업 추진 계획을 수립하였다.

본 사업은 하드웨어 사업을 중심으로, 토목 및 건축, 기자재 및 시설 공여, 연수생 초청, 전문가 파 견 등으로 구성되었다. 연수생 초청은 주로 설비 및 공장 운영, 도정·건조·저장 기술, 전기제어, 설비 작동 방법 등의 내용으로 연수가 진행됐고, 전문가 파견의 경우는 전기, 기계, 수확 후 기술, $\mathrm{RPC}$ 운영 분야로 구성되어 이루어졌다.

본 사업의 적절성을 평가하기 위한 설문의 내용 및 그 분석결과, 5 점 만점의 척도를 가지고, 계획과 의 일치성(3.90), $\mathrm{RPC}$ 시설의 질(4.15), 처리능력(4.00), 공여된 영농기계들의 현지 조건과의 적 합성(3.50) 및 $\mathrm{RPC}$ 와의 적합성(3.40)을 조사한 결과, 비교적 높은 적절성을 나타낸 것으로 보인 다.

전문가 자문 활동은 $\mathrm{RPC}$ 운영과 관련하여 한국에서 $\mathrm{RPC}$ 운영, 전기, 기계, 수확 후 관리 등 4 분야 4 명이 파견되어 이루어졌다. 전문가 자문 활동의 적절성에 대한 설문 조사 결과, 5점을 기준으로, 자문내용(3.60), 방법(3.40), 태도(4.60), 기술(4.00), 기간(4.00), 파견된 전문가 수(4.00)를 기록 
하여, 비교적 양호한 것으로 나타났다.

연수생 초청 사업과 관련하여, 운영자 과정 3명(3주)과 관리자 과정 3명(2주) 등 총 6명이 연수 대 상이었으나, 최종적으로 운영자 과정 2 명, 관리자 과정 5 명 등 총 7 명이 연수를 받았다. 그러나 현 재 $\mathrm{RPC}$ 에 직접 근무하고 있는 연수생은 2 명에 불과한 것으로 나타났다. 이와 관련하여 연수 대상 자들이 실제 $\mathrm{RPC}$ 에 근무하는 비율이 높지 않은 것을 감안한다면, 대상자 선정에 신중하여야 할 것 으로 판단된다. 비록 연수생들이 주 정부 등의 상위 기관의 관련 업무에 종사함으로써 RPC 사업에 간접적으로 도움을 줄 수는 있겠지만, 차후 연수생 초청 사업에 대해서는 귀국 후 일정 기간 직접 관련된 업무에 종사할 수 있도록 수원국에 요청하는 등 제도적 보완장치를 마련해 두는 것이 필요 할 것으로 판단된다.

즉 $\mathrm{RPC}$ 사업은 시설 · 설비 등의 공여와 설치 등 하드웨어 사업과 운영 · 관리 등 소프트웨어 사업 이 함께 이루어져야 효과를 제고할 수 있음을 고려할 때, 본 사업에서 토목 및 건축, 시설의 처리 능력 등은 현지 실정을 감안하여 적절하게 계획이 수립이 되었다고 평가할 수 있다. 그러나 일부 설 비(예를 들어, color sorter 및 length grader)는 수원국 내 고품질 쌀의 선호도나 판매 가능성에 대한 고려가 부족한 상태에서 최신의 현대적 설비가 제공됨으로써 비교적 활용도가 떨어지는 것으 로 파악되었다.

또한 상대적으로 쌀의 수매, 마케팅, 인력관리 등 경영기술 관련 소프트웨어 향상을 위한 연수는 거 의 이루어지지 않았으므로, 앞으로 연수생 초청 및 전문가 파견 시 이에 대한 보완이 필요할 것으로 보인다.

\section{다. 사업계획 수립 시 리스크와 이해관계자 분석 여부 평가}

사업시행 과정에서 나타날 수 있는 예상 가능한 리스크는 사업 계획 수립단계에서 적절하게 파악되 고, 준비되었다고 할 수 있다. 특히 일괄수주 용역과 $\mathrm{PMC}$ 용역으로 구분하여 접근함으로써, 사업 의 전문성을 높였고, $\mathrm{RPC}$ 시설 및 영농 기자재 등의 통관, 현지 수송, 치안 확보 방안 등이 실시 협 의 단계에서 논의되었다.

이해관계자 분석관련, $\mathrm{RPC}$ 사업관련 이해관계자는 농민, 유통업자, 기존의 $\mathrm{RPC}$ 운영업자, 소비자 등이라고 할 수 있다. 기존에 오로라주에 미곡종합처리장 대신 소규모 도정시설이 있었으나 농민들 에게 큰 이익을 제공하지는 못하였으며, 건조 및 저장 시설이 부족한 실정이었다. 따라서 본 RPC 사업에서는 건조 능력과 보관 시설을 강화하였다. $\mathrm{RPC}$ 는 농민들에게는 소득증대를, 소비자에게는 
품질 좋은 쌀을 제공할 수 있는 시설이기 때문에 사실상 사업추진 과정에서 갈등 요소는 없었던 것 으로 판단된다.

다만, 오로라주 정부 차원에서 $\mathrm{RPC}$ 운영에 대한 장 - 단점, $\mathrm{RPC}$ 건립 후 경영 계획 및 지원 등에 대한 분석이 부족했던 점은 앞으로 유사 사업에서 충분히 고려해야 할 것으로 보인다.

\section{라. 사업대상지 선정의 적절성}

오로라주는 2004년 현재 20,052.14 ha에서 쌀을 재배하고 있었으며, 총 생산량은 64,235.58 톤 으로써, ha 당 연 평균 3.20톤을 수확하고 있다. 생산량 대비 자급율은 $153.71 \%$ 에 이른다. 한편 오로라주의 수확 후 처리 시설은 건조 및 저장 시설이 부족한 실정이며 대개 노변에서 천일 건조 를 하고 있기 때문에, 특히 우기 수확 시 건조 및 저장시설은 필수적이라 할 수 있다. 이러한 부족 을 이유로 인근 주의 유통업자들이 오로라주에서 벼를 싸게 수매한 후 다른 주에서 가공을 한 후 도 정된 쌀을 오로라주에 되팖으로써, 생산자인 농민은 물론 소비자들이 모두 불이익을 보는 상황이었 다.

오로라주 정부는 사업 대상 후보지역으로 Baler 시와 Maria Aurora 시를 2곳을 제안한 바 있는데, 예비조사 단계에서는 부지면적, 도로 접근성, 주도로서의 상징성 등을 감안하여 Baler시로 선정하 였다. 오로라주의 쌀 농업, 수확후 처리시설의 현황, 설문 조사 결과 등을 종합할 때 본 사업의 사 업대상지 선정은 매우 적절하게 이루어졌다고 평가할 수 있다.

\section{2. 효과성 (Effectiveness)}

효과성 평가에서는 사업 목표의 달성도, 사업 활동의 목표 달성 기여도, 사업 수혜자에 대한 기여도 및 내용과 성과 등을 주로 평가한다.

\section{가. 사업 목표의 달성도와 기여도}

본 사업의 주목적은 현대화된 미곡 생산기술 및 설비를 갖춘 $\mathrm{RPC}$ 설립을 통하여 미곡생산에서 판 매에 이르기까지 효율적 생산관리시스템 및 영농 기계화 구축과 이에 따른 농민의 소득 증진을 도 모하는데 있으며, 세부목적은 $\mathrm{RPC}$ 의 설립, 생산에서 판매에 이르는 효율적 생산관리 시스템 구축, 영농기계화 구축, 농민의 소득 증대 도모라는 네 가지로 구분될 수 있다. 
$\mathrm{RPC}$ 설립은「설계-시공-가동」과「관리-자문」이 구분되어 분야별 전문 회사 및 전문가들이 효 율적으로 업무를 추진하게 됨으로써 성공적으로 이루어졌다고 평가된다.

생산관리 시스템의 구축은 설비 등의 하드웨어 요소와 경영 관리 등의 소프트웨어 요소로 구성되는 데, 하드웨어 요소는 현대적인 일괄 처리 설비를 도입하고 성공적으로 운영됨으로써 그 목표를 달 성하였다고 평가할 수 있다. 소프트웨어 요소는 수원국 내 쌀의 유통과정 등에 대한 면밀한 조사가 필요하고, 그에 대응하는 직원들의 능력이 증진되지 않으면 달성하기 어려운 요소이며, 이러한 요 소는 연수생 초청사업이나 전문가 파견단계에서 다루어질 수 있는 것이다. 설문조사 결과, 전문가 파견 및 연수생 초청사업에 대한 목표 대비 달성정도에 대해서는 각각 평균 3.41점과 3.38점으로 상대적으로 낮은 응답을 보였으며, 개방형 설문지 조사 결과에서도 훈련과 워크숍을 통해 직원의 업무능력 향상이 필요하다는 응답이 많이 제기되었다. 따라서 $\mathrm{RPC}$ 운영과 관련된 소프트웨어 요소 에 대한 직원들의 업무 능력 향상이 요구되며, 이를 위한 현직 훈련이 더 강화될 필요가 있는 것으 로 평가된다.

영농 기계화 구축은 공여된 영농 기자재를 이용하여 농업 생산력을 높이려는 의도로 이루어졌다. 이는 기존의 영농 관행을 바꾸지 않고 단순히 영농 기자재를 제공하는 것으로서는 달성이 어려운 목표이다. 실제로 본 목표를 달성하기에는 공여된 영농 기자재의 수량이 제한적이었다. 또한 영농 기계화를 구축하기 위해서는 $\mathrm{RPC}$ 가 논을 임대 또는 소유하여 공여된 영농 기자재를 이용하여 직 접 영농을 하고, 그 결과를 농민들에게 보여주는 시범적 운영방식이 있을 수 있으나, 아직까지는 그 러한 기반 시설을 갖추지 못하고 있다. 이러 면을 종합할 때, $\mathrm{RPC}$ 건립을 통한 영농 기계화 구축의 목표는 본 사업목적과는 다소 부적절하거나 또는 자체 농장 운영 등과 같은 대안적 방안이 부족하 였다는 평가를 내릴 수 있다.

$\mathrm{RPC}$ 건립을 통한 농민의 소득 증대라는 목표는 매우 직접적인 혜택을 줄 수 있는 목표라고 할 수 있다. 현재 RPC가 농민의 소득 증대에 기여하는 방식은 다음의 여섯 가지로 요약이 가능한데, 벼 수매 과정에서의 가격, 수송 가격에 대한 보상, 건조 시설의 이용에 따른 소득 증대 기회, 수매용 자루의 무료 제공, 사전 설정 가격유지, 예측 가능한 수매 등이 있다. 따라서 농민들의 소득을 증대 시킨다는 $\mathrm{RPC}$ 건립 목적은 $\mathrm{RPC}$ 가 도입되기 이전의 관행과 대비하여 볼 때, 그 목적을 충분히 달 성하고 있는 것으로 평가할 수 있다.

\section{나. 사업의 목표집단에 대한 기여도와 내용}

사업의 목표 집단에 대한 기여도와 관련된 설문조사 결과, $\mathrm{RPC}$ 는 수원국의 쌀 관련 정책수단(평균 
3.75점), 농민의 소득 증대(평균 3.65점), 목표지역의 빈곤 감소(평균 3.50점) 등에 효과가 있는 것 으로 응답되었다. 다만, 농민들이 $\mathrm{RPC}$ 를 적절하게 이용하고 있는가의 여부에 대한 응답 결과는 다 른 질문보다 상대적으로 다소 낮게 나타났다. 실제 사후 조사 기간 파악된 자료에 의하면, 중부 오 로라 지역의 농민 632 명 중 251명(39.7\%)가 RPC를 이용하고 있으며, 점차 이용자가 늘어가고 있 는 것으로 조사되었다.

$\mathrm{RPC}$ 건립사업은 목표 집단에 다음과 같은 의미 있는 기여를 하는 것으로 평가할 수 있다. 오로라 주는 RPC 운영을 통해 얻은 수익으로 주 정부의 재정자립에 기여할 수 있으며, 쌀 가격 안정, 고용 창출 및 대 주민 신뢰향상이라는 효과를 얻었다. 농민들의 입장에서는 수확 후 손실을 방지하고, 건 조 및 수매 과정을 통해 노동력을 절감하고, 소득을 증대시킬 수 있는 기회를 가지게 되었으며, 소 비자들은 품질 좋은 쌀을 합리적 가격으로 이용할 수 있게 되었다.

한편 개방형 질문으로 조사한 RPC의 효과에 대한 응답 결과, 긍정적 효과에 대한 응답이 부정적 효 과보다 많다는 점은 본 사업이 목표를 달성하고, 목표집단에 대한 효과를 주고 있다는 사실을 나타 낸다.

부정적 효과로서 지적된 과다한 운영비용의 소요, 쌀의 가격 통제를 위한 정책 부족 등은 $\mathrm{RPC}$ 의 지 속성을 확보하기 위해서라도 새로운 대안이 모색되어야 할 영역이라 할 수 있겠다.

\section{다. 연수생 초청활동의 효과성}

한국에서 이루어진 연수사업에 참여한 응답자들의 응답결과에 기초할 때 연수사업은 전반적으로 그 목표를 달성하고, 효과를 주고 있는 것으로 평가할 수 있다. 업무에의 도움 정도는 물론 지식, 태도, 행동 및 기술 변화에 많은 도움이 되었던 것으로 응답하고 있다. 또한 연수 기간관련 응답 역 시 평균 3.44 를 나타내어, 연수 활동의 목표를 달성하는데 적절한 것으로 판단할 수 있다.

\section{3. 효율성(Efficiency)}

효율성 평가에서는 수원 행정체계, 협력단의 사업체계, 사업의 산출물 달성 정도 및 완성도, 사업실 시 기법의 유용성, 사업관리 체계의 효율성, 사업 활동의 이행여부 등을 중점 평가하게 된다.

\section{가. 수원국 행정체계}


필리핀의 $\mathrm{RPC}$ 사업은 「국가식량청(NFA; National Food Authority)」, 「필리핀 토지은행(Land Bank, Philippine)」, 「농지개혁부(DAR; Department of Agrarian Reform)」,「농업부(DA; Department of Agriculture)」 등 여러 기관의 협동으로 추진되었다. RPC 사업에 대한 전국적인 조정기능을 가진 기관은 없으며, $\mathrm{RPC}$ 운영과 관련된 기술적 자문을 농업부 산하 「수확 후 연구지 도국(BPRE; Bureau of Postharvest Reseach and Extension)」이 담당하고 있다.

본 사업은 2004년부터 추진되었는데, 초기 추진과정에서는 수원국의 RPC 관련 기관의 협조보다는 오로라주 상원의원 및 주지사의 적극적인 사업 유치 노력이 큰 영향을 주었다. 이후 본격적으로 사 업이 추진되면서 본 사업에 대한 수원국의 집행기관은 농업부(Department of Agriculture)와 오 로라주정부로 결정이 되었다. 그러나 농업부는 사후에 협조체계를 갖추는데 참여하며 $\mathrm{BPRE}$ 를 통 하여 기술적인 자문이나 사업 진행에 대한 모니터링 수준의 역할에 머물게 되었다.

사업이 진행되던 과정에서 오로라주 정부는 사업 추진을 위해 2007년 12 월 4일 개최된 의회 회의 에서「사업추진위원회(PSC; Project Steering Committee)」와「기술자문단(TWG; Technical Working Group)」을 두는 것을 결의하는 조례를 통과시켰다. $\mathrm{RPC}$ 에서는 이들 두 조직 외에「사 업경영팀 (PMO; Project Management Office)을 설치하는 것으로 2007년 사업계획서에서 밝히 고 있다. 이러한 구성은 수원국의 $\mathrm{RPC}$ 사업과 관련된 지역 단위 기단들을 이들 조직에 전부 참여시 킴으로써 $\mathrm{RPC}$ 운영의 지원을 위한 전체적인 틀을 갖추었다고 할 수 있다. 그러나 실제로 이들 조 직은 사후평가까지 구성되지 않은 것으로 조사되었으며, 특히 위원들이 정부조직 중심으로 구성되 어 있어, 농민 대표 등 이해 당사자의 욕구를 수렴하는데 한계가 있을 것으로 판단되었다.

이런 면을 종합할 때 수원국의 행정체계는 아직까지 다소 미흡한 것으로 평가되었으며, 차후 유사 사업에서는 수원국의 $\mathrm{RPC}$ 관련 기관 중 책임 있는 부서를 사전에 결정하여야 할 것으로 판단된다. 오로라 $\mathrm{RPC}$ 에서는 특히 $\mathrm{RPC}$ 경영과 관련된 분야별로 실질적인 자문 역할을 할 수 있는「자문위 원회(Advisory Group)」를 운영하거나 이해 당사자의 욕구를 수렴할 수 있는 장치를 두어야 할 것 으로 보인다.

\section{나. KOICA 사업체계와 사업실시 기법의 유용성}

본 사업을 추진하면서 $\mathrm{KOICA}$ 에서는 앞서 지적하였듯이, 일괄수주 용역(Turn-key base)과 PMC 용역으로 구분하여 접근하였다. 일괄수주 용역은 건축, 기자재 지원, 연수생 초청, 전문가 파견 등 의 업무를 일괄적으로 수행할 업체를 입찰 경쟁을 통해 선정하였고, $\mathrm{PMC}$ 용역은 국내 유일의 수확 후 관련기술을 연구하고 있는 농촌진흥청 농업공학연구소와 $\mathrm{RPC}$ 설계 검토, 물품 검수, 적합성 및 
기자재 설치 검수 등 전문 기술적인 부분을 종합 자문, 관리하는 수의 계약을 체결하였다. 일괄수준 용역을 통해 선정된 업체는 건축 및 RPC 시설 생산 업체와 콘소시엄으로 시설을 완공하였다.

연수생 초청은 RPC 시설 생산업체인 (주) 신흥강판을 통해 이루어졌는데, 관리자 과정은 5명에 대 해 15 일, 운영자 과정은 2 명에 대해 21 일간 실시되었다. 사업과 관련한 성공요인과 애로 사항은 자 체 연수평가 결과를 통해 밝히고 있다. 전반적으로는 $\mathrm{RPC}$ 운영에 필요한 기본적인 내용은 충분히 준비되고 전달되었다고 평가하나, 준비 기간이 촉박하였고, 연수 대상자의 수와 대상자가 바뀌는 애로사항을 보고하고 있다. 특히 동 업체가 연수교육을 처음실시한 관계로 불안정한 분위기에서 연 수가 이루어졌음을 지적되었다.

전문가는 $\mathrm{RPC}$ 전기, 기계 및 수확 후 기술 분야에 대해서는 각각 1 명씩 2 주간, 그리고 $\mathrm{RPC}$ 운영 분야는 1 명이 1 개월간 파견되는데, 수확 후 기술분야는 $\mathrm{PMC}$ 기관인 농촌진흥청의 전문가가 파견 되었고, 일괄수주업체와 $\mathrm{PMC}$ 업체간 협조는 잘 이루어진 것으로 판단된다.

본 사업을 추진하면서 관련 전문기술 분야의 오류를 사전에 차단하고자 계획한 $\mathrm{KOICA}$ 의 사업체계 및 접근은 매우 효율성이 높은 것으로 평가할 수 있다. 그러나 세부적인 내용의 효율성에 대해서는 다소 보완이 필요할 것으로 판단된다. 특히 외국인에 대한 연수 경험이 없던 업체에서 연수를 주관 함으로써 발생한 문제 및 연수생이 확정되지 않고 중도에 변경이 생기는 문제, 또한 연수 대상자가 연수 후 $\mathrm{RPC}$ 에 근무하지 않는 문제는 $\mathrm{RPC}$ 운영, 기술적 문제 발생 시 부정적인 영향을 줄 수 있는 부분으로 평가된다. 실제로 종료 평가보고서 역시 이 부분에 대해서는 $\mathrm{RPC}$ 준공 이후 현지에서 실 습을 겸한 실무적인 기술 전수를 하는 것이 사업성과 제고에 더 도움이 될 것으로 제시하고 있다. 향후 동일 사업에 대해서는 연수생 초청 사업과 전문가 파견 활동을 통합하여 현지에서 이론 및 실 무 기술을 제공하는 것이 더욱 효율성을 가질 것으로 평가된다.

\section{다. 사업의 산출물 달성 정도 및 완성도}

$\mathrm{RPC}$ 시설 및 공여된 영농 기자재는 사업 계획에 제시된 목표를 달성하였으나 다만 건물 설계에 대 해서는 실제 $\mathrm{RPC}$ 운영 과정에서 개선의 여지가 있는 것으로 파악되었다. 저장 공간에 대한 격벽 미 설치, 부산물 처리 공간에 대한 고려 미흡, 하나의 구조물 보에 color sorter와 length grader를 함 께 설치함으로써 나타나는 진동의 문제 등이 이에 해당한다. 또한 공여된 설비 및 기자재 역시 각 설비 자체의 우수성에도 불구하고, 부분적으로 세심한 고려가 필요한 것으로 파악되었다.

사업의 효율적 추진과 관련, $\mathrm{RPC}$ 건립 사업의 시간과 비용 측면의 효율적 수행 여부에 대한 응답 
결과는 각각 평균 3.45 와 3.25 로 나타났다. 설문 응답에서 시간적인 측면이 비용 절감적인 측면보 다 더 높게 나타나고 있는 것은 $\mathrm{RPC}$ 건립이 목표했던 기간 내에 차질 없이 완공되었기 때문인 것 으로 판단된다. 비용 절감 측면에 대한 긍정적 반응은 설치된 시설이 사업 지역의 수확 후 기술에 대한 기존 관행이나 경제적 여건에 비추어 상당히 높은 수준의 현대적인 것으로 설치되었기 때문인 것으로 판단된다. 또한 $\mathrm{RPC}$ 운영 및 경영 기술의 효율적 이전 여부에 대해서는 평균 3.25 점으로서 상대적으로 낮게 평가되고 있는 것을 알 수 있다. 파견된 전문가 자문 활동의 효율성에 대해서는 평 균 3.60점으로 비교적 높은 것으로 나타났다.

한 가지 고려할 상황으로는, 고유가 등 특수한 상황이 발생할 경우 석유를 연료로 사용하는 건조기 의 운영비용이 매우 부담이 되기 때문에, 이에 대한 대책이 요구된다 하겠다. 이를 위해 RPC 부산 물을 이용한 건조 시설의 도입 필요성에 대한 검토가 필요하며, 적정기술 수준에서 공여되는 설비 및 기자재의 질과 양을 고려하는 사업 설계가 이루어져야 할 필요가 있다.

이런 면들을 종합할 때 사업의 산출물 달성 정도는 효율적이었다고 평가할 수 있으나, 완성도의 측 면에서는 다소의 보완이 요구된다고 할 수 있다. 따라서 수원국에서 활용되고 있는 관련 기술에 대 한 검토와 이를 사업에 반영시키는 사업설계를 고려할 필요가 있다.

\section{라. 사업관리 체계의 효율성}

본 사업의 추진을 관리하기 위한 활동은 전반적으로 효율적이었다고 평가할 수 있다. KOICA에서 는 2006년 10월 9일-14일에 중간평가와 2007년 12월 1일-10일에 종료평가를 실시하였으며, 일 괄수주 용역업체에서는 2006년 3월 9일 기공식 이후, 2006년 12월 6일-11일에 걸쳐 완성된 RPC 시설을 최종 평가한 후, 준공식을 가졌다. 오로라 RPC에서는 2007년 2월에서 3월까지 RPC 설비 에 대한 시험 가동을 하여 설비의 안정성 등을 확인하였다.

오로라 $\mathrm{RPC}$ 의 사업관리 행정체계는 2007 년까지는 $\mathrm{RPC}$ 와 관련된 모든 회계 및 공문은 주 정부에 서 직접 관할하였으나, 2008년부터 주 정부에서 독립 회계를 하도록 하고 있다. 감사는 분기별로 1 회씩 감사위원회(Commission of Audit)에서 3명이 나와 실시하고 있는 것으로 확인되었다.

조직 체계의 효율성에 대해서는 평가하기가 어려우나, 조직운영상의 개선점은 발견할 수 있었는데, 사실상 RPC 운영에 전적인 책임을 지고 있는 운영책임자와 행 - 재정실장(Accountant IV) 겸 회계 담당 등 4명이 현재 정식으로 보직을 받지 않은 직무대리로 근무하고 있는데 이들 중 운영책임자와 행 - 재정실장은 한국에서의 연수사업에도 참여한 바 있고, 각각 기계전문가와 회계사로서의 자격 
을 갖추었고, $\mathrm{RPC}$ 를 실제로 2 년 가까이 운영하고 있는 경험이 있다. 따라서 이들을 정식 보직으로 발령을 내어야 책임감을 갖고 $\mathrm{RPC}$ 운영을 할 수 있을 것으로 판단된다.

\section{마. 사업 활동의 이행여부}

$\mathrm{RPC}$ 건립은 2006년 3월 9일 기공식 이후 2007년 1월 26일 준공식을 가질 때까지 전체 사업을 계 획된 바와 같이 원활하게 추진하였으며, 사업 실시과정에서 세부적인 일부 항목에 대해서는 수정이 이루어졌지만, 사업추진 업체와 $\mathrm{KOICA}$ 간 원활한 협조를 통해 문제를 해결하였다. 기존 계획에서 수정이 이루어진 점들은 대개 건축물 시공과 관련된 사항이고, 설계 풍속이나 저장고 면적 및 판넬 의 두께 등은 현지 실정을 사전에 정확하게 파악하지 못하여 발생되는 문제로 판단된다. 연수생 초 청 사업의 경우 대상자의 수와 기간에 다소 조정이 이루어진 부분은 수원국의 문제이나 연수 담당 기관에게 부담을 줄 수 있는 부분으로 보완이 필요하다 하겠다.

\section{4. 파급 효과 (Impact)}

사업의 파급효과는 사업의 직·간접적인 효과를 의미한다. 사업 파급효과(Impact) 또는 영향력에 대한 사후평가는 사업의 상위목표 달성 가능성과 긍정적 사업 효과, 사업의 역량개발 및 제도 강화 에 대한 기여도 등에 초점을 두고 이루어진다.

\section{가. 사업의 상위 목표(Overall goal) 달성가능성 및 긍정적 효과}

본 사업의 상위 목표는 농민소득 증대를 통한 인류 기본 욕구의 해결에 기여하는 것이다. 이에 대해 $\mathrm{RPC}$ 는 수확된 벼의 건조, 보관, 도정 및 판매에 이르는 과정을 일괄 처리하는 시설로써, 그 기능의 수행을 통해 생산자 및 소비자를 모두 만족시킬 수 있다고 판단되었다.

$\mathrm{RPC}$ 의 주요 기능은, 벼의 수매과정에서 농업인에 대한 소득을 보전하고, 쌀의 품질을 높이며, 쌀 의 유통 기능을 통해 쌀 가격을 안정시킬 수 있는 것으로 인식된다. 특히 오로라주에는 현대적인 미곡종합처리장이 없어서 그 동안 개인 유통업자에 의해 농민이 많은 손해를 입어 왔던 점을 감안 할 때, $\mathrm{RPC}$ 를 통한 사업목표로서의 농민의 소득 증대에 기여할 수 있다고 평가할 수 있다.

사후 평가 시 농민에 대한 면담을 통해 확인한 결과에 기초할 때, $\mathrm{RPC}$ 사업은 제대로만 기능을 한 다면, 농민들의 소득 증대에 충분히 기여할 수 있다고 판단되며, 결국 본 사업의 상위 목표를 달성 할 수 있을 것으로 평가된다. 
농민들이 $\mathrm{RPC}$ 를 이용하는 주요 이유는 다음과 같이 여섯 가지로 요약이 가능한데, 첫째로는 수매 가를 현금 또는 수표로 $1 \sim 2$ 내에 지급하고 있으며, 둘째, 수매 시 품질에 따른 정당한 가격을 부여 하고 있고, 셋째, 빈 자루를 무료로 빌려주고 있으며 넷째, 약속된 시간에 수매를 하고 있다. 다섯 째, 개인 유통업자들이 가끔 위조지폐로 결제하는 것을 방지하고 있고, 마지막으로 기존 유통업자 보다 높은 가격으로 쌀을 수매하고 있다.

본 사업의 긍정적 효과와 관련한 설문 결과, $\mathrm{RPC}$ 는 주 수혜자인 농민에게 평균 3.72 점 정도로 알 려져 있다고 응답되었다. 특히 $\mathrm{RPC}$ 는 쌀의 건조 및 저장 관행 그리고 도정 관행에 큰 영향을 준 것 으로 응답되고 있으며, 쌀 생산이나 마케팅 개선 그리고 소득 창출 기회의 증대 등에 대해서는 보통 이상의 파급 효과를 주는 것으로 나타났다.

$\mathrm{RPC}$ 사업의 효과가 어느 정도 전국적으로 확산되고, 복제될 것인가에 대한 파급 효과에 대해, 응 답자들은 평균 3.29 점으로 보통 이상으로 가능할 것으로 평가하고 있다.

한편 RPC 사업은 농민의 소득 증대라는 기본 목표 외에 KOICA 또는 한국의 위상을 홍보하는 부 수적인 파급효과를 가지고 있는데, RPC에서 생산된 쌀은 포장에 $\mathrm{KOICA}$ 로고가 찍혀 있으며 도정 된 쌀의 품질이 매우 높아 현지에서는 오로라 쌀이라는 공식적인 브랜드보다는 KOICA 쌀이라는 이 름으로 회자되고 있을 정도이다. $\mathrm{KOICA}$ 로고의 삽입은 관행적으로 이루어진 것이지만, 쌀의 품질 등에 의해 소비자에게 부정적인 영향을 줄 수도 있기 때문에 품질 관리 및 KOICA 로고의 사용 등 에 대해서는 오로라주 정부, $\mathrm{RPC}$ 및 $\mathrm{KOICA}$ 사무소와의 협정 제정이 필요할 것으로 판단된다.

이러한 결과에 기초할 때 $\mathrm{RPC}$ 건립사업은 농민의 소득 증대라는 직접적인 목표 달성을 통해 인류 기본 욕구의 해소라는 상위 목표 달성에 긍정적으로 기여했다고 평가된다. 이러한 기본 목적 외에 도 $\mathrm{RPC}$ 사업은 수확 후 영농 기술의 개선에 큰 파급력을 끼쳤으며, 한국과 $\mathrm{KOICA}$ 의 위상을 드높 이는 부수적인 효과도 가지고 있는 것으로 판단되었다. 또한 오로라주에서의 $\mathrm{RPC}$ 건립사업은 필리 핀 RPC 사업 운영의 한 모델로 기능할 수 있을 것이라는 예측이 가능하다.

\section{나. 사업의 역량 개발 및 제도 강화 기여도}

사업의 역량 강화는 RPC 사업장을 자조적으로 운영할 수 있는 제반 능력의 개발을 의미한다고 할 수 있다. 기본적으로 한국에서 연수를 받은 7 명의 인력 중 2 명이 현장에 근무하고 있어 제한적이기 는 하지만 $\mathrm{RPC}$ 설비 자체를 운영하는데 큰 어려움이 없는 것으로 판단된다. 실제로, $\mathrm{RPC}$ 에서는 사업 역량 개발을 위한 노력을 전개하고 있고, 자체적으로 고용한 담당 직원이 쌀을 생산하는 전 과 
정에서 이중 확인을 하는 등 품질관리 및 재고관리에 큰 비중을 두고 있다. 2008년도에는 쌀 수매 인력에 대해 노동교육 세미나(Pakyaw Labor Group Seminar)를 가져 직원들의 업무 관리에도 관 심을 두고 있었다.

업무의 지속성 확보 및 경영관리를 위해 2006년 11월에는 「2007 Business Plan」(2007년 3월 및 6월 개정), 2007년 7월에는 「Five-Year Development Plan」을, 그리고 2006년 11월에는 $\ulcorner\mathrm{RPC}$ Operations Manual」(2007년 3월 및 6월 개정)을 각각 발간하여 RPC 운영에 필요한 기 본 조건을 자체적으로 준비하는 열정을 보이기도 했다.

$\mathrm{RPC}$ 관련 제도 강화를 위해 오로라주 정부는 2007년 12월 4일에 열린 주 의회에 조례 161호 를 제정한 바 있는데, 이 조례에서 본 사업의 원래 명칭이었던 「The Construction of Modern Integrated Rice Processing and Milling Complex (RPC) in the Philippines」를 농민, 소 비자 및 마케팅 개발 과정에서의 편의, 그리고 한국과 필리핀의 상호 신의를 인정하기 위해

$\ulcorner$ Philippines-Korea Rice Processing Complex(RPC) Project」로 변경하였다. 또한 RPC 운 영을 주 정부의 경제 사업으로 공식 인정하였는데, 이는 $\mathrm{RPC}$ 에 대한 인력 및 재정적 지원, 회계 및 감사 등에 행정적 · 정책적 · 제도적 지원이 이루어질 수 있는 기반이 마련되었다는 매우 중요한 의 의를 갖는다. 그리고 $\mathrm{RPC}$ 의 운영자금을 지원할 수 있는 조항을 마련한 바 있으며, 실제로 운영 자 금을 지원하고 있는 것으로 파악된다.

한편 제도 강화에 대한 기여도를 알아보기 위한 설문조사 결과, 응답자들은 $\mathrm{RPC}$ 사업이 정책결정자 에게 $\mathrm{RPC}$ 의 필요성에 대한 인식 제고에 평균 3.35점, $\mathrm{RPC}$ 에 대한 농민의 인식 제고에 평균 3.10 점, 그리고 언론 매체 등에 대한 노출에 대해 평균 3.20 점 정도의 영향을 준 것으로 응답하고 있다. 또한 $\mathrm{RPC}$ 의 직접적인 수혜자가 누가 될 것인가에 대해 질문을 한 결과, $\mathrm{RPC}$ 직원들은 $\mathrm{RPC}$ 와 관 련된 모든 이해 당사자들이 혜택을 볼 것이라는 압도적인 응답 경향을 보이고 있다. 이중 부재지주 와 $\mathrm{RPC}$ 가 이익을 볼 것이라는 점에 대해서는 응답자가 한 명도 없었다. 이러한 논의를 종합할 때, 본 $\mathrm{RPC}$ 건립 사업은 오로라주 정부의 제도 개선 및 직원들의 역량 강화에 파급 효과를 준 것으로 평가할 수 있을 것이다.

\section{5. 지속가능성 (Sustainability)}

지속가능성 평가는 사업 종료 후 운영관리, 기술, 재무적 자립도를 확보하였는지를 확인하는 과정 을 통하여 사업이 지속적으로 발전할 가능성이 있는지를 평가하는 것이다. 지속가능성 평가는 수혜 자의 시설, 장비관리 및 유지가능성에 대한 평가, 그리고 사업의 자립발전성에 대한 평가에 초점을 
두고 이루어진다.

\section{가. 시설 유지 가능성}

다음과 같은 이유를 통해, 사업 시행 후 건립된 $\mathrm{RPC}$ 가 큰 차질 없이 운영될 것으로 전망된다. 첫째, $\mathrm{RPC}$ 시설 운영을 위한 기계적 조작을 위한 기술이전이 연수 사업을 통해 효과적으로 전수되었다. 둘째, 수원국의 관련 부서인 $\mathrm{BPRE}$ 등을 통한 자문이 이루어지고 있으며, 셋째, 이미 2년간의 운영 을 통해 무리 없이 운영된 경험이 쌓여 있다.

$\mathrm{RPC}$ 직원들의 $\mathrm{RPC}$ 운영의 기술 능력에 대한 자체 평가 결과, 설비 유지 능력 및 $\mathrm{RPC}$ 회계에 대 해서는 보통 이하의 응답을 보이고 있다. 이는 전자동의 현대적 기계 설비에 대해 익숙하지 않거나, 부품 등의 사후 조달의 어려움을 반영하는 것으로 판단된다. $\mathrm{RPC}$ 회계 능력에 대한 응답 결과는 전 문 영역에 속하는 부분이고, $\mathrm{RPC}$ 에서는 회계사가 근무하고 있으므로 큰 문제는 없을 것으로 판단 된다.

$\mathrm{RPC}$ 설비 운영, $\mathrm{RPC}$ 경영, 생산물 마케팅은 보통보다 다소 높은 응답을 보이고 있다. 이중 고객 봉사 능력은 다른 영역에 비해 다소 높으나 그 점수가 높지 않다.

반면에 RPC 시설 및 설비에 대한 관리 및 운영 정도에 대해서는 자신들의 능력에 대한 응답 경향에 비해 더 높은 결과를 보여주고 있다. 운영의 적절성에 대한 응답이 다소 낮은 것은 $\mathrm{RPC}$ 의 운영을 단순한 쌀의 수매·건조 · 저장 · 도정 - 판매의 과정만 아니라 비료와 농약 등 영농 투입요소도 함 께 구매할 수 있는 서비스가 이루어지기를 바란다는 농민들의 기대사항이 반영되었기 때문인 것으 로 판단된다.

이러한 점을 종합할 때, 시설 유지 가능성은 다음의 몇 가지 사항을 개선할 경우 충분히 달성될 수 있을 것으로 평가된다. 첫째, 소모품 조달 문제는 시설 공여 시 1 년 정도 소요되는 소모품이 함께 전달되었으나, 그 이후의 소모품 문제에 대해서는 현지에서 구입하기가 어려운 현 실정을 반영하 여, 시설 제공 업체에서 관련 소모품에 대한 목록을 작성하고 사전에 필요 여부를 타진하여 적시에 공급해줄 수 있는 체계가 마련될 필요가 있다. 이를 위해서는 상시 의사전달 통로가 만들어져야 할 것으로 보인다. 둘째, 공여된 영농 기계 및 수송수단의 문제 개선이다. 본 사업에서는 트럭 한 대만 수송 수단으로 공여되었는데, 년 2회 수확이 이루어지고 있는 상황에서 수확 시기에 쌀의 수매 및 판매를 위해서는 절대적으로 추가의 수송 수단이 공급되어야 한다. 만약에 트럭이 고장이 날 경우 $\mathrm{RPC}$ 운영의 가장 기본인 쌀의 수매가 이루어지지 않음으로써 $\mathrm{RPC}$ 가동이 중지되는 사례도 발생할 
수 있기 때문이다. 운반 수단인 지게차 역시 1대만 공여되었고, 이도 역시 수송수단과 유사한 문제 를 초래할 가능성이 있다. 한편 콤바인의 경우 세 대가 지원이 되었지만, 현지의 영농 관행이나 논 의 조건 등에 비추어 적합성이 다소 떨어져 활용도가 높지 않은 상태이다. 따라서 차후 유사 사업을 전개할 때는 트럭과 지게차의 공여 대수를 늘리고, 현지 적합성이 떨어지는 영농 기계는 과감히 공 여를 하지 않는 것이 바람직할 것으로 판단된다.

\section{나. 사업의 자립 발전성}

본 사업의 자립 발전 가능성은 기본적으로 $\mathrm{RPC}$ 운영을 통해 어느 정도의 수익을 낼 수 있는가의 문 제와 이를 위한 제도적, 행정적, 재정적 지원의 여부에 달려 있다고 할 수 있다.

$\mathrm{RPC}$ 운영의 지원을 위한 제도적, 행정적, 재정적 지원은 앞서 지적한 바와 같이 바와 같이, 오로라 주 정부의 조례 제정을 통해 그 기반이 마련되었다고 할 수 있다. 특히 재정 지원과 관련하여, 오로 라주 정부에서는 $\mathrm{RPC}$ 운영을 통해 수익을 낼 경우 지원된 자금을 되갚는 차입금의 형태로 운영자 금을 지원하는 방식을 취하고 있다. $\mathrm{RPC}$ 운영 3년차(2009년)부터 수익을 낼 것으로 가정하고 필요 한 운영자금의 $20 \%$ 를 사전에 지원하는 것으로 조례를 제정하였다.

$\mathrm{RPC}$ 의 보고에 의하면, 2007년도의 경우 주 정부에서 필요한 인건비전부와 $23,199,999.94$ 페소의 운영자금을 지원하였고, 결산 후 $16,744,571.8$ 페소(지원금의 $72.2 \%$ 를 주 정부로 환원한 것으 로 되어 있다. 2008년도에는 4명의 공무원을 $\mathrm{RPC}$ 운영자로 지원하고, 운영자금 $13,984,777.76$ 페소와 기타 자금(실험장비 58,988.00페소, 판매용 자루 값 200,000.00페소, 수매용 자루 값 $240,000.00$ 페소)으로 498,988.00페소를 지원하고 있다. RPC가 주 정부에서 운영하고 있는 시설 이기 때문에 쌀의 수매와 판매 등에 따른 부가가치세(12\%)를 면제하고 있어 농민에게도 이익을 주 고, 유통 과정에서의 경쟁력을 확보할 수 있는 계기가 되고 있다. 이러한 자료에 기초할 때 RPC 운 영을 위한 오로라주 정부의 지원체계는 매우 적절하게 마련되어 있다고 평가할 수 있다.

한편 RPC 운영을 통한 수익성은 장기적으로 볼 때 충분히 자립할 수 있을 것으로 평가할 수 있다. 2007년 대비할 때 2008년도의 기준 기간이 짧음에도 불구하고, 수매량은 $35.1 \%$ 가 증가하였지만 비용은 $87.3 \%$ 나 증가하였고, 판매량은 $6.4 \%$ 감소하였으나, 판매 금액은 $22.2 \%$ 가 증가하였다. 수 매량 대비 수매 비용의 급격한 증가 및 판매량 감소에도 불구하고 판매 금액이 높아진 비정상적인 결과는 2008년 상반기 필리핀의 식량 위기에 따른 곡물 가격의 폭등에 기인한 것으로 판단된다.

오로라 RPC는 현재 최대 운영 능력의 35\% 선에서 가동되고 있다. 「2007 Business Plan」 및 
「Five-year Development Plan」의 경영 계획에 의하면, 2007년도에는 최대 운영 능력의 $30 \%$ 수준에서, 2008년도에는 70\% 수준을, 2009년부터는 최대 운영을 하는 목표를 수립하고 있다. $\mathrm{RPC}$ 의 최대 능력을 활용하지 못하는 이유로서는, 첫째로 2007년의 경우는 $\mathrm{RPC}$ 시설의 가동, 쌀 수매 및 판매망 확보 등이 처음으로 이루어졌기 때문에 시행착오가 있었으며, 둘째로 2008년도의 경우에는 고유가와 쌀 가격의 폭등으로 인한 식량 위기 때문에 쌀의 수매 및 판매 등의 RPC 운영과 관련된 적절한 의사결정을 내리기가 매우 어려웠기 때문이라고 여겨진다.

$\mathrm{RPC}$ 자체에서 작성한 2008년도 1월부터 8월까지 손익을 분석 결과, 순 이익은 49,951.18 페소 (2008년 10월 환율 47페소 반영시 약 1,063달러) 정도에 불과하다. 수입 구성 항목별로 볼 때 순 수익은 도정된 쌀의 판매보다는 오히려 영농 기자재의 대여 등과 같은 기타 수입의 비용이 더 많은 데, 이는 도정 쌀의 전체 판매금액 중 $98.6 \%$ 를 차지하는 생산비의 비중이 반영되고 있기 때문이라 고 판단된다. 특히 2008년 상반기 유가 상승으로 인한 건조 비용이 매우 높았기 때문이다. 따라서 건조에 들어가는 연료비의 부담을 줄이지 않는 이상 쌀 판매에 따른 수입보다 기타 수입이 더 많은 비중을 차지할 가능성이 높다고 할 수 있다.

지출을 살펴보면, 직원들의 월급과 임금 및 보안을 위한 경비가 전체 지출의 $63.6 \%$ 를 차지하고 있 고, 수송차량 유지에 들어가는 휘발유 및 윤활유 비용이 $9.6 \%$ 를 차지하고 있다. RPC 운영을 통한 수익성 분석결과가 $\mathrm{RPC}$ 최대 처리능력의 $35 \%$ 수준에서 운영된 결과라는 점을 감안할 때, 장기적 으로 자립적인 운영이 가능한 수익률을 달성할 수 있을 것으로 평가된다. 또한 쌀 수매에 응하는 농 가가 늘어나고 있고, 관리 및 경영과 관련된 지식과 노우 하우(know-how)가 축적되고 있는 것이 이에 기여하는 요소라 할 수 있다. 이 중 $\mathrm{RPC}$ 운영의 생산비 중 건조 비용을 절감하는 방안이 모색 되어야 하겠다.

한편 본 $\mathrm{RPC}$ 사업의 자립 발전성과 관련한 설문 분석결과, $\mathrm{RPC}$ 운영의 핵심 조건의 하나인 농민 들의 이용 전망에 대해서는 3.45 점으로 가장 높은 응답을 보이고 있고, 직원들의 경영 능력도 3.40 점으로 어느 정도 바람직한 전망을 보이고 있다. $\mathrm{RPC}$ 운영과 관련된 예산의 확보 및 외부의 보조 없이 자립적으로 운영할 가능성에 대해서는 각각 3.25점과 3.10점으로 보통 수준에서의 응답을 보 이고 있다. 이러한 결과는 비록 오로라주 정부에서 운영 자금을 지원한다는 조례가 제정되었지만, 실제 $\mathrm{RPC}$ 운영에 소요되는 운영 자금을 충족시킬 수 있을 것인가에 대한 우려를 반영하고 있는 것 으로 판단된다.

농민과 $\mathrm{RPC}$ 직원간의 의사소통은 3.20점으로 보통보다 다소 높은 수준에서 이루어지고 있으나, 농민들의 $\mathrm{RPC}$ 운영지침이나 체계에 대한 이해도에 대해서는 보통으로 응답하고 있다. 이에 따라 
$\mathrm{RPC}$ 가 농민의 협조 없이는 존립하기 어렵다는 점에서 농민과의 관계에 의사소통이나 $\mathrm{RPC}$ 홍보를 위한 노력이 더욱 요구된다 할 수 있겠다.

\section{6. 사업 요인 만족도 (Satisfaction)}

본 사업의 사후 평가와 관련하여, 사업의 각 요인에 대한 만족도는 비교적 높은 것으로 평가할 수 있다. 사업의 범위 및 전체 사업 예산에 대한 만족도가 다른 요소에 비해 만족도가 높게 나타나고 있으며, 반면에 지방 정부의 지원에 대해서는 다소 낮게 응답되었다.

\section{IV. 정책제언}

본 사업에 대한 평가 결과에 기초하여 향후 유사한 사업을 전개하는데 고려하여야 할 제언은 사업 설계, 사업운영과 지원, 기타 고려사항의 세 가지로 구분하여 제시할 수 있다.

\section{1. 사업설계}

첫째, 지역의 특성을 반영한 시설의 유형과 규모를 결정할 필요가 있다. 이를 위해 사전 조사 시 사 업 후보 지역의 $\mathrm{RPC}$ 현황, 시설 운영 관행 등에 대한 정보의 파악이 필요하다. 특히 석유를 이용한 건조기의 경우 생산비 부담이 매우 높음으로 왕겨 등 부산물을 이용한 건조기를 병행 도입하는 방 안을 검토할 필요가 있다.

둘째, $\mathrm{RPC}$ 건립을 위한 설계 시 저장고의 격벽 설치, 부산물 처리 공간, 지역의 풍속 등 오로라 $\mathrm{RPC}$ 의 실제 운영에 기초한 세부적인 경험을 활용할 필요가 있다.

셋째, 사업 구성요인에 대한 신중한 검토가 요구된다. 연수활동과 전문가 파견 활동은 $\mathrm{RPC}$ 준공 후 현지에서 직접 실시하는 것이 사업비를 줄이면서 효과를 더욱 높일 수 있을 것으로 판단되고, 특히 트럭과 지게차 등 수송 및 운반수단의 수량 확대가 절실하다. 영농 기자재의 경우 현지 적합성을 고 려하여 과감한 조정을 할 필요가 있다.

넷째, 시설의 유지 · 관리를 위한 방안을 강화할 필요가 있다. 첨단 기계의 고장에 대한 대처나 소모 품의 제공 방법 등이 사전에 설계되어 적시에 제공되어야 하며, 이는 단순히 $\mathrm{A} / \mathrm{S}$ 기간을 확대하는 것만이 아니라, 설비 제공업체에서 정기적으로 $\mathrm{RPC}$ 와 접촉하는 통로를 만들어주어야 함을 의미한다. 


\section{2. 사업 운영과 지원}

국가 간 양자 사업으로 공여된 $\mathrm{RPC}$ 는 기본적으로 공적 서비스 지향의 성격을 가지고 있으므로, $\mathrm{RPC}$ 소유 및 운영권에 대한 신중한 검토가 요구된다. 개인 또는 농민단체 등으로의 위임을 통한 $\mathrm{RPC}$ 운영은 자칫 이익 추구형 RPC 운영으로 변모될 수 있으며, 경영능력에 따라서는 도산의 우려 도 있을 수 있다. 따라서 공여된 $\mathrm{RPC}$ 에 대해서는 최소한 정부 또는 주 정부의 소유권이 계속 유지 될 수 있는 방안을 마련할 필요가 있다.

또한 운영에 있어서 수원국 관련 기관의 적극적 참여와 활용 방안이 필요하다. $\mathrm{RPC}$ 운영과 관련된 경영 기술은 국가마다 상황이 매우 다르므로 한국의 경험이 경쟁력을 갖는데 한계가 있다. 필요한 경우, 수원국의 관련 기관에 대한 실습 자재 등을 지원함으로써 사업의 파급 효과를 더욱 확대시킬 수 있을 수 있는 방안의 검토가 요구된다.

마지막으로, 사업 종료 후에도 직원들에 대한 능력 향상 워크숍 등에 대한 지원방안을 검토할 필요 가 있다.

\section{3. 기타}

$\mathrm{RPC}$ 생산물의 포장에 $\mathrm{KOICA}$ 브랜드 및 로고 등을 사용하는 것과 관련한 양해 각서 작성 등의 대 비책이 요구된다. 유사사업이 확대될 경우, 품질 관리의 미비로 자칫 한국의 위상에 악영향을 줄 수 도 있기 때문이다.

또한 $\mathrm{R} / \mathrm{D}$ 체결시 $\mathrm{RPC}$ 운영에 대한 면세 조항을 요구할 필요가 있다. 오로라 $\mathrm{RPC}$ 의 경우 주 정부 사업이기 때문에 세금이 면제되고 있고, 면세되는 금액이 운영자금 등으로 활용이 가능하여, 민간 $\mathrm{RPC}$ 와의 경쟁력 확보에 도움을 줄 수 있기 때문이다. 